DOI: https://doi.org/10.32838/2523-4803/70-3-12

удК 330.334

\title{
Пальчевич Г.Т.
}

кандидат економічних наук, професор,

професор кафедри фінансів, банківської справи та страхування,

Центральноукраїнський національний технічний університет

\section{Palchevich Galina}

Central Ukrainian National Technical University

\section{ОРІСНТИРИ ТА НАПРЯМИ \\ УДОСКОНАЛЕННЯ ДЕРЖАВНОГО РЕГУЛЮВАННЯ ІННОВАЦІЙНОГО РОЗВИТКУ ЕКОНОМІКИ}

У статті доведено необхідність та охарактеризовано значення державного регулювання інноваиійного розвитку економіки. Виокремлено методи прямого та непрямого державного регулювання. Визначено орієнтири державного регулювання інноваційного розвитку та шляхи його здійснення. Розкрито пріоритетні напрями інновачійної діяльності в Україні. Досліджено фінансування інноваційної діяльності промислових підприємств за рахунок коштів державного бюджету. Проаналізовано стан бюджетного фінансування інновачійної діяльності та трансферу технологій за пріоритетними напрямами інноваційної діяльності загальнодержавного рівня. Здійснено оцінювання податкового стимулювання інноваційної діяльності. Запропоновано шляхи вдосконалення бюджетних і податкових інструментів впливу на активізацію інноваційного розвитку.

Ключові слова: державне регулювання, інновачійний розвиток, інновачійна діяльність, державна інноваційна політика, бюджетне фінансування, трансфер технологій, податкове стимулювання, податок на прибуток.

Постановка проблеми. Реалізація цілей і завдань сталого розвитку потребує розроблення ефективної державної економічної політики, обгрунтування іiі положень, методів, важелів та інструментів, спрямованих на створення сприятливих умов для сталого економічного зростання.

Визначальним вектором розвитку сучасної світової економіки є зростання конкурентоспроможності національних економік на основі науково-технологічних інновацій. Успішне розроблення, впровадження та ефективне застосування новітніх технологій можливі за активної участі держави в розвитку інноваційної сфери. Основні цілі державної інноваційної політики стосуються заохочення наукових відкриттів, запровадження новітніх технологій, забезпечення прогресивних перетворень у виробничій сфері, зміцнення безпеки та обороноздатності країни, поліпшення екологічної ситуації, застосування інноваційних процесів у всіх сферах суспільного життя. Необхідність державного втручання в процес впровадження інновацій пояснюється тривалістю науково-виробничого циклу, високими витратами й невизначеністю кінцевого результату.

Аналіз останніх досліджень і публікацій. Питання державного регулювання інноваційної діяльності $\epsilon$ предметом наукових досліджень багатьох закордонних та вітчизняних учених. Зокрема, методологічні аспекти формування комплексу організаційних, економічних, фінансових механізмів регуляторного впливу держави на активізацію інноваційних процесів в економічній та соціально-гуманітарній сферах отримали висвітлення в наукових працях Л.Дж. Гітмана [1], В. Гриньової [2], Н. Демчишина [7], А. Денисенка [10], І. Крисоватого [6], М. Крупки [7], С. Онишко [8], Б. Санто [14], Л. Федулової [16], Е. Харгадона [17], С. Чистова [3], У. Шарпа [18] та інших науковців. Водночас, незважаючи на значну кількість опублікованих праць, їх наукову та практичну цінність, сьогодні проблема державного регулювання інноваційного розвитку економіки потребує подальших комплексних досліджень 3 урахуванням сучасних особливостей та перспектив соціально-економічного розвитку України.

Формулювання цілей статті. Мета статті полягає в обгрунтуванні основних орієнтирів та визначенні напрямів удосконалення державного регулювання інноваційної діяльності.

Виклад основного матеріалу. Світовий досвід переконливо свідчить про те, що забезпечення сталого зростання національної економіки потребує впливу держави на активізацію технологічних інновацій та соціокультурних зрушень. Саме держава має ініціювати та забезпечувати правові, організаційні, економічні, фінансові та соціальні передумови формування інноваційної моделі розвитку, створювати сприятливе середовище для науково-інноваційної модернізації технічного, технологічного та інтелектуального потенціалу. 
Державне регулювання економіки передбачає втручання державних органів влади за допомогою різних методів та інструментів у розвиток основних економічних процесів задля забезпечення позитивних соціально-економічних результатів. Об'єктивною необхідністю такого втручання $€$ неспроможність ринку забезпечити виконання економічної політики держави [2, с. 16].

Слід зауважити, що методи державного регулювання економіки поділяються на прямі та непрямі.

Прямі методи державного регулювання безпосередньо впливають на функціонування суб'єктів ринку. До них належать інструменти, нормативно-правові акти, обов'язкові до виконання завдання макроекономічних планів і цільових програм, державні замовлення, централізовано встановлені ціни, нормативи, стандарти, ліцензії, квоти, державні бюджетні витрати, ліміти, грошова емісія тощо.

Методи непрямого державного регулювання, що опосередковано впливають на поведінку суб'єктів ринку, включають такі інструменти, як фіскальні (податки на банківську діяльність і на прибуток від депозитів фізичних осіб); бюджетні (дотації, субсидії, субвенції); грошово-кредитні; інвестиційні; амортизаційні (введення механізму прискореної амортизації); інноваційні (визначення стратегічних напрямів розвитку науки та пріоритетних наукоємних технологій) [3, с. 22].

Отже, до найбільш поширених прямих методів державного стимулювання інноваційного розвитку можна віднести пряме державне фінансування інноваційних проєктів, створення ефективної інноваційної інфраструктури, підготовку кадрів для інноваційної сфери тощо. Непрямі ж методи спричиняють опосередкований вплив на активізацію запровадження інноваційних продуктів та технологій. Стосуються вони визначення стратегічних цілей інноваційного розвитку, гнучкого використання податків та податкових пільг, норм амортизаційних відрахувань, ставок рефінансування, кредитних пільг, регулювання цін, тарифів тощо.

3 огляду на обмеженість фінансових ресурсів у сучасних умовах держава повинна віддавати перевагу непрямим методам стимулювання інноваційних процесів, зокрема, через розширення механізмів податкових стимулів в інноваційній сфері, які мають стати дієвим важелем державного регулювання [6, с. 28].

Л. Федулова вважає, що державне регулювання інноваційної діяльності означає цілеспрямований вплив органів державного управління на економічні інтереси інститутів інноваційної сфери [16, с. 391].

Головними орієнтирами державного регулювання інноваційного розвитку є забезпечення реалізації пріоритетних напрямів державної інноваційної політики, створення сприятливих умов для життєдіяльності суспільства, суб'єктів господарювання, підвищення рівня добробуту та якості життя населення.

Відповідно до Закону України «Про інноваційну діяльність» державне регулювання інноваційної діяльності здійснюється шляхом:

- визначення й підтримки пріоритетних напрямів інноваційної діяльності;

- формування й реалізації державних, галузевих, регіональних і місцевих інноваційних програм;

- створення нормативно-правової бази та економічних механізмів для підтримки й стимулювання інноваційної діяльності;

- захисту прав та інтересів суб'єктів інноваційної діяльності;

- фінансової підтримки виконання інноваційних проєктів;

- стимулювання комерційних банків та інших фінансово-кредитних установ, що кредитують виконання інноваційних проєктів;

- встановлення пільгового оподаткування суб' єктів інноваційної діяльності;

- підтримки функціонування й розвитку сучасної інноваційної інфраструктури [11].

Підтримка державою пріоритетних напрямів інноваційного розвитку може здійснюватися шляхом безпосереднього інвестування бюджетних коштів в об’єкти інноваційної діяльності. В табл. 1 відображено динаміку фінансування інноваційної діяльності промислових підприємств за рахунок коштів державного бюджету.

Таблиця 1

Динаміка показників бюджетного фінансування інноваційної діяльності промислових підприсмств

\begin{tabular}{|l|c|c|c|c|c|c|c|}
\hline \multicolumn{1}{|c|}{ Показник } & \multicolumn{9}{c|}{ Роки } & \multicolumn{2}{c|}{ Відхиленн (+, -) } \\
\cline { 2 - 8 } & $\mathbf{2 0 1 5}$ & $\mathbf{2 0 1 6}$ & $\mathbf{2 0 1 7}$ & $\mathbf{2 0 1 8}$ & $\mathbf{2 0 1 9}$ & $\begin{array}{c}\mathbf{2 0 1 9} \text { до } \\
\mathbf{2 0 1 5} \mathbf{~ p p . ~}\end{array}$ & $\begin{array}{c}\mathbf{2 0 1 9} \text { до } \\
\mathbf{2 0 1 8} \mathbf{p p .}\end{array}$ \\
\hline $\begin{array}{l}\text { Загальний обсяг фінансування, } \\
\text { млн. грн. }\end{array}$ & 13813,7 & 23229,5 & 9117,5 & 12180,1 & 14220,9 & 407,2 & 2040,8 \\
\hline $\begin{array}{l}\text { Фінансування з державного } \\
\text { бюджету, млн. грн. }\end{array}$ & 55,1 & 179,0 & 227,3 & 639,1 & 556,5 & 501,4 & $-82,6$ \\
\hline $\begin{array}{l}\text { Фінансування з державного } \\
\text { бюджету, \% до загального } \\
\text { обсягу фінансування }\end{array}$ & 0,4 & 0,8 & 2,5 & 5,2 & 3,9 & 3,5 & $-1,3$ \\
\hline
\end{tabular}

Примітка: дані наведені без урахування тимчасово окупованої території Автономної Республіки Крим, м. Севастополя та частини тимчасово окупованих територій у Донецькій та Луганській областях.

Джерело: розраховано та побудовано автором з використанням джерела [4] 
Як бачимо, обсяги фінансування інноваційної діяльності промислових підприємств за 2015-2019 рр. зросли на 501,4 млн. грн. (в 9,1 разів), що свідчить про зміцнення державної підтримки інноваційного розвитку промисловості. Хоча дещо тривожним $є$ зменшення у 2019 р. порівняно з 2018 р. бюджетного фінансування інноваційної діяльності промислових підприємств на 82,6 млн. грн. При цьому варто зазначити, що частка коштів державного бюджету в загальному обсязі витрат на інновації в промисловості $€$ досить незначною.

Для активізації інноваційної діяльності в Україні передусім слід задіяти широкий спектр економічних регуляторів, зокрема податкових, кредитно-фінансових. Маються на увазі система податків, їхні ставки та пільги; порядок та норми амортизаційних відрахувань; система фінансування, кредитування й ціноутворення; фінансові дотації, субсидії; бюджетні позики; антимонопольні заходи; система експертизи, контролю інвестицій; приватизація державної власності та незавершеного будівництва [10, с. 79].

Законом України «Про пріоритетні напрями інноваційної діяльності в Україні» задекларовано, що пріоритетними напрямами інноваційного розвитку $є$ науково й економічно обгрунтовані напрями провадження інноваційної діяльності, що спрямовані на забезпечення економічної безпеки держави, створення високотехнологічної конкурентоспроможної екологічно чистої продукції, надання високоякісних послуг та збільшення експортного потенціалу держави 3 ефективним вико- ристанням вітчизняних та світових науково-технічних досягнень [12].

Урядом України визначено такі пріоритетні напрями інноваційної діяльності загальнодержавного рівня на 2017-2021 рр.:

- освоєння нових технологій транспортування енергії, впровадження енергоефективних, ресурсозберігаючих технологій, освоєння альтернативних джерел енергіï;

- освоєння нових технологій високотехнологічного розвитку транспортної системи, ракетно-космічної галузі, авіа- й суднобудування, озброєння та військової техніки;

- освоєння нових технологій виробництва матеріалів, їх оброблення та з'єднання, створення індустрії наноматеріалів та нанотехнологій;

- технологічне оновлення та розвиток агропромислового комплексу;

- впровадження нових технологій та обладнання для якісного медичного обслуговування, лікування, фармацевтики;

- широке застосування технологій більш чистого виробництва та охорони навколишнього природного середовища;

- розвиток сучасних інформаційних, комунікаційних технологій, робототехніки [5].

У табл. 2 наведено дані щодо бюджетного фінансування інноваційної діяльності та трансферу технологій за стратегічними пріоритетними напрямами соціальноекономічного розвитку. Відображені в таблиці показ-

Бюджетне фінансування інноваційної діяльності та трансферу технологій

Таблиця 2 за стратегічними пріоритетними напрямами

\begin{tabular}{|c|c|c|c|c|c|c|}
\hline \multirow{2}{*}{ Пріоритетні напрями інноваційної діяльності } & \multicolumn{2}{|c|}{2016 p. } & \multicolumn{2}{|c|}{$2017 \mathrm{p}}$. & \multicolumn{2}{|c|}{2018 p. } \\
\hline & тис. грн. & $\%$ & тис. грн. & $\%$ & тис. грн. & $\%$ \\
\hline $\begin{array}{l}\text { Освоєння нових технологій транспортування } \\
\text { енергії, впровадження енергоефективних, } \\
\text { ресурсозберігаючих технологій, освоєння } \\
\text { альтернативних джерел енергії }\end{array}$ & 20101,96 & 10,33 & 15212,73 & 5,87 & 17094,31 & 5,87 \\
\hline $\begin{array}{l}\text { Освоєння нових технологій } \\
\text { високотехнологічного розвитку транспортної } \\
\text { системи, ракетно-космічної галузі, авіа- та } \\
\text { суднобудування, озброєння та військової техніки }\end{array}$ & 6274,01 & 3,22 & 11710,93 & 4,52 & 18729,10 & 6,42 \\
\hline $\begin{array}{l}\text { Освоєння нових технологій виробництва } \\
\text { матеріалів, їх оброблення та з'єднання, } \\
\text { створення індустрії наноматеріалів та } \\
\text { нанотехнологій }\end{array}$ & 16345,33 & 8,4 & 35979,56 & 13,89 & 45315,30 & 15,55 \\
\hline $\begin{array}{l}\text { Технологічне оновлення та розвиток } \\
\text { агропромислового комплексу }\end{array}$ & 115563,30 & 59,4 & 151412,50 & 58,43 & 153444,23 & 52,65 \\
\hline $\begin{array}{l}\text { Впровадження нових технологій та обладнання } \\
\text { для якісного медичного обслуговування, } \\
\text { лікування, фармацевтики }\end{array}$ & 5023,95 & 2,58 & 4871,42 & 1,88 & 5356,06 & 1,84 \\
\hline $\begin{array}{l}\text { Широке застосування технологій більш чистого } \\
\text { виробництва та охорони навколишнього } \\
\text { природного середовища }\end{array}$ & 23687,27 & 12,18 & 29182,88 & 11,26 & 32213,93 & 11,05 \\
\hline $\begin{array}{l}\text { Розвиток сучасних інформаційних, } \\
\text { комунікаційних технологій, робототехніки }\end{array}$ & 7562,39 & 3,89 & 10759,69 & 4,15 & 19299,91 & 6,62 \\
\hline Всього за пріоритетами & 194558,20 & 100 & 259129,71 & 100 & 291452,84 & 100 \\
\hline
\end{tabular}

Джерело: розраховано та побудовано автором з використанням джерела [15] 
ники свідчать про те, що найбільша частка бюджетного фінансування інноваційної діяльності та трансферу технологій зосереджена на стратегічному пріоритеті «Технологічне оновлення та розвиток агропромислового комплексу» (у 2016 р. показник становив 59,4\%; у 2017 р. - 58,43\%; у 2018 р. - 52,65\%). Це позитивно в тому аспекті, що достатнє техніко-технологічне забезпечення сільського господарства сприяє покращенню фінансово-економічного стану й підвищенню рівня конкурентоспроможності вітчизняних аграріїв та економіки країни загалом.

Найменше державою фінансується стратегічний пріоритет «Впровадження нових технологій та обладнання для якісного медичного обслуговування» (у 2016 р. показник становив 2,58\%; у 2017 р. - 1,88\%; у 2018 р. - 1,84\%). Така тенденція є вкрай негативною, особливо сьогодні, в час гострої необхідності концентрації всіх зусиль, зокрема фінансових, на протидії світовій пандемії, що стала серйозною загрозою національній безпеці держави.

Загальний обсяг бюджетного фінансування стратегічних пріоритетів інноваційної діяльності та діяльності у сфері трансферу технологій у 2018 р. становив 291452,83 тис. грн., або 94,9\% у загальних обсягах бюджетного фінансування інноваційної діяльності, що на 12,5\% більше порівняно з 2017 р. Щодо ВВП означений обсяг фінансування у 2018 р. становив 0,0082\% (у 2017 р. показник становив 0,0087\%, у 2016 р. $0,0082 \%)[15$, c. 30$]$. Для активізації інноваційної діяльності необхідно збільшити обсяги цього фінансування.

Світовою практикою підтверджена ефективність податкового стимулювання інноваційного розвитку економіки. Використовуючи гнучкі податкові інструменти, держава спроможна підвищувати рівень мотивації суб'єктів господарювання до здійснення інноваційної діяльності, стимулювати розроблення та впровадження ними новітніх інноваційних продуктів та технологій.

Запровадження політики податкового стимулювання інноваційної діяльності фактично означає винайдення способів та меж балансування між державними та приватними інтересами, результатом яких $є$ обопільне задоволення інтересів кожного суб'єкта. Держава, поступаючись своїм поточним фіскальним інтересом під час податкового стимулювання інноваційної діяльності, вправі розраховувати на задоволення інших потреб, таких як інвестування вивільнених ресурсів у виробництво, фундаментальні дослідження, прикладні розробки, зменшення відтоку з країни-носіїв інтелектуального потенціалу. Платник податків в обмін на понесення значних фінансових затрат 3 довгостроковою окупністю вправі розраховувати на зниження податкового тиску, дотримання гарантій незмінності законодавства у довгостроковій перспективі тощо [13, с. 172].

Дієвим інструментом податкового стимулювання інноваційної діяльності є ПДВ. Мається на увазі використання можливості звільнення від сплати ПДВ окре- мих видів інвестиційної діяльності, встановлення зниженої ставки податку на окремі інноваційні продукти та звільнення від сплати ПДВ імпорту інноваційної продукції.

Позитивний вплив щодо активізації інноваційної діяльності спричиняє надання інноваційним підприємствам пільг з податку на прибуток. Йдеться насамперед про звільнення чи часткове звільнення від сплати податку на прибуток підприємств, які реалізують наукові проєкти, впроваджують у технологічний виробничий процес інноваційний продукт. Доцільним є запровадження «податкових канікул» протягом кількох років щодо прибутку, отриманого у сфері інноваційної діяльності підприємства.

Варто зважати на те, що ефективність податкових пільг для стимулювання інноваційної діяльності забезпечується стабільним податковим законодавством, мінімізацією адміністративних процедур під час їх оформлення.

Стратегічним напрямом удосконалення застосування бюджетних і податкових інструментів впливу в національній економіці є налагодження кооперації між державою, яка зацікавлена в підвищенні інноваційної активності й добробуту громадян, бізнесом, готовим фінансувати новітні розробки, та науковими інститутами, науково-дослідними установами на взаємовигідних умовах задля інтеграції освітньо-наукової сфери й реального інноваційно орієнтованого виробництва, що приведе до появи науково-виробничих структур із повним технологічним циклом від інноваційної роботи до виробництва [7, с. 60-61].

Перспективними для успішної реалізації стратегічних пріоритетів державного регулювання інноваційного розвитку економіки є вдосконалення інноваційного законодавства, застосування принципів грантового фінансування інноваційних розробок, подальший розвиток освітніх інновацій, поглиблення міжнародного співробітництва в інноваційній сфері, формування державної інноваційної інфраструктури.

Висновки. Таким чином, розвиток ефективної та конкурентоспроможної економіки потребує дієвого державного регулювання інноваційної діяльності. Цілеспрямований вплив держави на інноваційні процеси полягає у створенні сприятливих умов для розроблення та просування інноваційних продуктів та технологій. Сучасні орієнтири державного регулювання економіки передбачають вихід країни на новий технологічний рівень, зміцнення конкурентоспроможності національної економіки, покращення добробуту та якості життя населення. Пріоритетним завданням сучасної державної політики є вдосконалення бюджетних та податкових інструментів стимулювання інноваційної діяльності. Перспективним для подальших наукових досліджень є дослідження механізмів ефективного функціонування й розвитку інноваційної інфраструктури. 
Список літератури:

1. Гитман Л.Дж., Джонк М.Д. Основы инвестирования / пер. с англ. О. Буклемишев и др. Москва : Дело, 1999. 991 с.

2. Гриньова В., Новікова М. Державне регулювання економіки : підручник. Київ : Знання, 2008. 398 с.

3. Чистов С. та ін. Державне регулювання економіки : навчальний посібник. Київ : КНЕУ, 2004. 440 с.

4. Державна служба статистики України. URL: http://www.ukrstat.gov.ua (дата звернення: 25.04.2020).

5. Деякі питання визначення середньострокових пріоритетних напрямів інноваційної діяльності загальнодержавного рівня на 2017-2021 роки : Постанова Кабінету Міністрів України від 28 грудня 2016 р. № 1056. URL: https://www.kmu.gov.ua/ua/npas/249657691 (дата звернення: 25.04.2020).

6. Крисоватий I. Напрямки вдосконалення податкового стимулювання інноваційних процесів в Україні. Світ фінансів. 2013. № 4. С. 28-36.

7. Крупка М., Демчишин Н. Сучасна парадигма фінансового регулювання інноваційної діяльності в Україні. Фінанси України. 2017. № 11. С. 47-63.

8. Онишко С. Державне регулювання кластеризації економіки як напрямок розбудови національної інноваційної моделі. Актуальні проблеми економіки. 2010. № 11. С. 55-61.

9. Податковий кодекс України. URL: http://zakon.rada.gov.ua/laws/show/2755-17 (дата звернення: 25.04.2020).

10. Денисенко М. та ін. Провайдинг інновацій : підручник. Київ : Видавничий дім «Професіонал», 2008.448 с.

11. Про інноваційну діяльність : Закон України. URL: http://zakon.rada.gov.ua/laws/show/40-15 (дата звернення: 25.04.2020).

12. Про пріоритетні напрями інноваційної діяльності в Україні : Закон України від 5 грудня 2012 р. № 3715-VI. URL: http://zakon5.rada.gov.ua/laws/show/3715-17 (дата звернення: 25.04.2020).

13. Рева Д. Роль податкових інструментів у регулюванні інноваційної активності. Адаптація до права ЄС регулювання економіки України в сучасних умовах. Харків : НДІ ПЗІР, 2015. С. 172-177.

14. Санто Б. Инновация и глобальный интеллектуализм. Инновации. 2006. № 9. С. 32-44.

15. Писаренко Т., Кваша Т. та ін. Стан інноваційної діяльності та діяльності у сфері трансферу технологій в Україні у 2018 році : аналітична довідка. Київ : УкрIНTЕI, 2019. 80 с.

16. Федулова Л. Інноваційна економіка : підручник. Київ : Либідь, 2006. 480 с.

17. Харгадон Э. Управление инновациями. Опыт ведущих компаний / пер. с англ. Москва : ООО «И.Д. Вильямс», 2007. $304 \mathrm{c}$.

18. Шарп У., Александер Г., Бейли Дж. Инвестиции / пер. с англ. А. Буренина, А. Васина. Москва : ИНФРА-М, 2010. $1028 \mathrm{c}$.

\section{References:}

1. Gitman L. Dzh., Dzhonk M.D. (1999) Osnovy investirovaniya [Fundamentals of investing]. Moscov : Delo (in Russian).

2. Ghrynjova V., Novikova M. (2008) Derzhavne reghuljuvannja ekonomiky [State regulation of Economy]. Kyiv : Znannja (in Ukrainian).

3. Chystov S. (2004) Derzhavne reghuljuvannja ekonomiky [State regulation of Economy]. Kyiv : KNEU (in Ukrainian).

4. Derzhavna sluzhba statystyky Ukrainy [Public service of statistics of Ukraine]. ukrstat.gov.ua. Available at: http://www.ukrstat.gov.ua (in Ukrainian).

5. Dejaki pytannja vyznachennja serednjostrokovykh priorytetnykh naprjamiv innovacijnoji dijaljnosti zaghaljnoderzhavnogho rivnja na 2017-2021 roky : Postanova Kabinetu Ministriv Ukrajiny vid 28.12.2016 r. № 1056. [Some issues of determining the medium-term priority areas of innovation at the national level for 2017-2021 № 1056. (2016, December 26)]. Available at: https:/www.kmu.gov.ua/ua/npas/249657691 (accessed: 25 April 2020).

6. Krysovatyj I. (2013) Naprjamky vdoskonalennja podatkovogho stymuljuvannja innovacijnykh procesiv v Ukrajini [Directions for improving tax incentives for innovation processes in Ukraine]. Svit finansiv, no. 4, pp. 28-36.

7. Krupka M., Demchyshyn N. (2017) Suchasna paradyghma finansovogho reghuljuvannja innovacijnoji dijaljnosti v Ukrajini [Modern paradigm of financial regulation of innovation in Ukraine]. Finansy Ukrajiny, no. 11, pp. 47-63.

8. Onyshko S. (2010). Derzhavne rehuliuvannia klasteryzatsii ekonomiky yak napriamok rozbudovy natsionalnoi innovatsiinoi modeli [State regulation of clustering of the economy as the direction of development of the national innovative model]. Aktualni problemy ekonomiky, no. 11, pp. 55-61.

9. Podatkovyj kodeks Ukrajiny. [Tax Code of Ukraine]. Available at: http://zakon.rada.gov.ua/laws/show/2755-17 (accessed: 25 April 2020).

10. Denysenko M. (2008) Provajdyngh innovacij [Innovation provision]. Kyiv : Vydavnychyj dim "Profesional" (in Ukrainian).

11. Pro innovacijnu dijaljnistj : Zakon Ukrajiny [On innovation: Law of Ukraine]. Available at: http://zakon.rada.gov.ua/ laws/show/40-15 (accessed: 25 April 2020).

12. Pro priorytetni naprjamy innovacijnoji dijaljnosti v Ukrajini : Zakon Ukrajiny vid 05.12.2012 r. № 3715-VI [On priority areas of innovation in Ukraine: Law of Ukraine № 3715-VI (2012, December 05)]. Available at: http://zakon5.rada.gov.ua/laws/show/3715-17 (accessed: 25 April 2020).

13. Reva D. (2015) Rolj podatkovykh instrumentiv u reghuljuvanni innovacijnoji aktyvnosti [The role of tax instruments in regulating innovation activity]. Adaptacija do prava JeS reghuljuvannja ekonomiky Ukrajiny $v$ suchasnykh umovakh. Kharkiv : NDI PZIR, pp. 172-177. 
14. Santo B. (2006) Innovatsiya i globalnyy intellektualizm [Innovation and Global Intellectualism]. Innovatsii, no. 9, pp. 32-44.

15. Pysarenko T., Kvasha T. (2019) Stan innovacijnoji dijaljnosti ta dijaljnosti u sferi transferu tekhnologhij v Ukrajini u 2018 roci : analitychna dovidka [The state of innovation and activity in the field of technology transfer in Ukraine in 2018 : analytical reference]. Kyiv : UkrINTEI (in Ukrainian).

16. Fedulova L. (2006) Innovacijna ekonomika [Innovative economy]. Kyiv : Lybidj (in Ukrainian).

17. Khargadon E. (2007) Upravlenie innovatsiyami. Opyt vedushchikh kompaniy [Innovation management. Experience of leading companies]. Moscov : OOO "I.D. Vilyams" (in Russian).

18. Sharp U., Aleksander G., Beyli Dzh. (2010) Investitsii [Investments]. Moscov : INFRA-M (in Russian).

\section{ОРИЕНТИРЫ И НАПРАВЛЕНИЯ \\ СОВЕРШЕНСТВОВАНИЯ ГОСУДАРСТВЕННОГО РЕГУЛИРОВАНИЯ ИННОВАЦИОННОГО РАЗВИТИЯ ЭКОНОМИКИ}

В статье доказана необходимость и охарактеризовано значение государственного регулирования инновациионого развития экономики. Выделены методы прямого и косвенного государственного регулирования. Определены ориентиры государственного регулирования инновационного развития и пути его осуществления. Раскрыты приоритетные направления инновационной деятельности в Украине. Исследовано финансирование инновационной деятельности промышленных предприятий за счет средств государственного бюджета. Проанализировано состояние бюджетного финансирования инновационной деятельности и трансфера технологий по приоритетным направлениям инновационной деятельности общегосударственного уровня. Осуществлено оценивание налогового стимулирования инновационной деятельности. Предложены пути совершенствования бюджетных и налоговых инструментов влияния на активизацию инновационного развития.

Ключевые слова: государственное регулирование, инновационное развитие, инновационная деятельность, государственная инновационная политика, бюджетное финансирование, трансфер технологий, налоговое стимулирование, налог на прибыль.

\section{GUIDELINES AND DIRECTIONS OF IMPROVEMENT OF STATE REGULATION OF INNOVATIVE DEVELOPMENT OF ECONOMY}

Successful development, implementation and effective application of the latest technologies are possible with the active participation of the state in the development of innovation. The article substantiates the main guidelines and identifies areas for improvement of state regulation of innovation. It is proved that the state should initiate and provide legal, organizational, economic, financial and social preconditions for the formation of an innovative model of development, create a favorable environment for scientific and innovative modernization of technical, technological and intellectual potential. The necessity and significance of state regulation of innovative economic development is revealed. Methods of direct and indirect state regulation are singled out. It is noted that the most common direct methods of state stimulation of innovative development include direct state funding of innovation projects, the creation of an effective innovation infrastructure, training for the innovation sphere and more. Indirect methods have an indirect effect on stimulating innovation. The guidelines of the state regulation of innovative development are determined and the ways of its implementation are indicated. The priority directions of innovative activity in Ukraine are revealed. The financing of innovative activity of industrial enterprises at the expense of the state budget is investigated. The state of budget financing of innovation activity and technology transfer in priority directions of innovation activity of the national level is analyzed. An assessment of tax incentives for innovation has been made. It is indicated that the effectiveness of tax benefits to stimulate innovation is ensured by stable tax legislation, minimization of administrative procedures for their design. Ways to improve budget and tax instruments to influence the intensification of innovative development, related to grant funding in universities, further reform of higher education, development of cooperation in the field of innovation with leading countries in terms of technology transfer, the formation of state innovation infrastructure.

Key words: state regulation, innovative development, innovative activity, state innovation policy, budget financing, technology transfer, tax incentives, income tax. 